\title{
QUALITY OF LIFE INDICATORS IN VISIONS OF ADOLESCENTS
}

\author{
Jitka Šimíčková-Č́ižková
}

\begin{abstract}
Our study focuses on application of the SEIQoL Method for investigating perceptions of quality of life by learners attending lower secondary schools. Our results indicate that the method mentioned above corresponds to the level of thinking of older learners (14-15 years of age). Younger learners (11-12 years of age) consider difficult to imagine their future and to generalize what they perceive as important in their lives. The structure of quality of life indicators corresponds to the age of respondents, and is also influenced by the urban or rural environment, in which the adolescents live.
\end{abstract}

\section{Key words}

Quality of Life, SEIQoL Method, Adolescents, Quality of Life Indicators.

\section{Introduction}

Reflections on quality of life are closely connected with opinion on satisfaction with our life. The World Health Organization (WHO) formulates the quality of life in the following way: "...Quality of life refers to subjective evaluation which is embedded in certain cultural, social and environmental contexts." (2004) Quality of life usually connects two components, i.e. subjective and objective one. An objective perception of quality of life can be identified by standard of living and physical health, subjectively perceived quality of life is identified with personal expectations. An important role in quality of life perception is played by individuals' conceptions of their own personalities and of their own lives and through their assertion within them.

From social scientists' point of view, most research is focused on investigations among the adult population. Interest in quality of life viewed by children and adolescents has become more and more an important theme only recently. Its difficulty is especially the creation and use of diagnostic tools. J. Mareš and his colleagues $(2006,2007,2008)$ investigate newly developed problems of children's quality of life diagnostics. They combine collection of empirical data with qualitatively focused investigation and apply quality of life diagnostics also to this age group. 
Our investigation must address the question of whether it is possible to use subjective questionnaires methods of the SEIQoL also for adolescents' population. The method does not establish criteria in advance but judges from respondents' opinions what they consider to be important in their lives. The method basis is a structured interview in which respondents reflect on things they expect from their lives. They define five life goals to a preparatory schedule and they numerically mark their importance (in percents). Our study tries to verify what testified value the method has for recognition of adolescents' quality of life.

\section{Research question, methods of investigation and examined sample}

While outlining the research question we consider that the theme of quality of life is quite distant for adolescences. So we let them reflect on what they find important and what they are afraid of in their lives, what can influence their lives in a positive way or, on the contrary, negatively according to their opinion. For questions quantification we used the schedule from the SEIQoL (Schedule for the Evaluation of Individual Quality of Life) method used by O'Boyle, McGee and Joyce (1994). The schedule is applied twice. In the first case they record five wishes they want to achieve in their lives. In the second case they record five worries from unpleasant life situations that might influence their lives negatively. Every respondent determinates the order of importance for every wish and worry. It is important that the file is $100 \%$ complete. This method requires direct contact with the questioner in order that a respondent can ask questions during recording. In this way they can ensure they work in accordance with the task.

The data collection was made by a method of accessible sample for pupils of the $6^{\text {th }}$ and $9^{\text {th }}$ grades at two lower secondary schools. It dealt with a sample of children who were either at the beginning or in the process of adolescence when they start thinking about their life goals and they begin to conceive of what sort of difficulties they might have to confront. Children of this age start imagining their future life and start to address the concrete fears from possible dangers they might be forced to face.

The researched sample consisted of 124 respondents aged from 11 to 16 years. A minor part of the sample included was created by 40 pupils who attended a village school (Albrechtice). A major part of the sample consisted of 84 pupils who attended a school in a town (Haviŕrov). The investigation was 
realised in June 2010 before the end of the school year. It had the character of Brains Trust. It used a schedule adapted from the one offered by the SEIQoL method. The pupils did not face any time pressure.

Tab. 1: Sample Rate according to Age and Sex

\begin{tabular}{|l|c|c|c|c|c|c|}
\hline School & 11-12 years old & $\mathbf{1 4 - 1 5}$ years old & & \multicolumn{2}{|c|}{ Sex } & \\
\hline & $\mathbf{6}^{\text {th }}$ Grade & $\mathbf{9}^{\text {th }}$ Grade & Total & Boys & Girls & Total \\
\hline Rural & 19 & 21 & 40 & 22 & 18 & 40 \\
\hline Urban & 39 & 45 & 84 & 49 & 35 & 84 \\
\hline Total & 58 & 66 & 124 & 71 & 53 & 124 \\
\hline
\end{tabular}

\section{Results and discussion}

The outcomes were processed by means of descriptive statistics. Criteria Importance - indicators dealing with life wishes or on the contrary with degree of worries from unpleasant situations were expressed by respondents in percentages so that it corresponds to the SEIQoL method used. However, in the case of statistic processing we used an absolute rate only so that it enabled easier orientation in the amount of various data. For an overview of the criteria we worked with, we publish the following table (Table no. 2).

The structure of indicators composition corresponds to respondents' age. They reckon "love" the most important value for the life of good quality and "death" as the most threatening possibility to the realisation of their wishes. "Family" is another positive and also negative indicator, i.e. in the sense of life mainstay or of its disturbance ("accident in a family", "divorce", "homelessness", and "parentlessness"). The third most important indicator is work "good job", "bad job", "money", "out of cash") that is connected to money and quality of life stability. The material criteria follow ("family house", "car"). Adolescents also consider importance of education in connection with work in positive and as well in negative consequences ("without education") for the quality of life.

For recognition of criteria consideration between the parts of the sample represented by younger ( $6^{\text {th }}$ grade $)$ and older ( $9^{\text {th }}$ grade $)$ pupils and place of living (rural and urban school) we used the statistic text $\chi^{2}$ at $d$. f. 1 . The results are shown in the Table no. 3 and Table no. 4. 
Tab. 2: Quality of Life Indicators

\begin{tabular}{|l|c|l|c|}
\hline $\begin{array}{c}\text { Positive Indicators } \\
\text { (Wishes - what I wish) }\end{array}$ & $\begin{array}{c}\text { Frequency } \\
\text { Rate }\end{array}$ & $\begin{array}{c}\text { Negative Indicators } \\
\text { (What I am afraid of) }\end{array}$ & $\begin{array}{c}\text { Frequency } \\
\text { Rate }\end{array}$ \\
\hline Love & 75 & Death & 82 \\
\hline Family & 73 & Illness & 51 \\
\hline Good Job & 61 & Bad, No Job & 34 \\
\hline Health & 53 & Accident in Family & 32 \\
\hline Money & 52 & Old Age & 29 \\
\hline Education & 34 & $\begin{array}{l}\text { Without Education, Stress } \\
\text { from School }\end{array}$ & 28 \\
\hline Family House & 33 & Lack of Success & 24 \\
\hline $\begin{array}{l}\text { Possession (car, plane, } \\
\text { mobile...) }\end{array}$ & 31 & Homelessness & 24 \\
\hline Friends & 25 & War & 24 \\
\hline Good luck, happiness & 22 & Fear from animals & 23 \\
\hline Animal & 15 & Out of cash & 22 \\
\hline Sport, nice body, muscles & 14 & Accident & 22 \\
\hline Success & 13 & Addictive Drugs & 19 \\
\hline Hobbies & 10 & Divorce & 15 \\
\hline Achieve One s Dream & 7 & Loneliness (Loveless) & 13 \\
\hline Travel & 5 & Betrayal, Disappointment & 11 \\
\hline High Marks & 3 & Bullying, Mocking & 11 \\
\hline & & Friendlessness & 8 \\
\hline & & Parentlessness & 8 \\
\hline & & Mugging, Robbery & 7 \\
\hline & & Prison & 6 \\
\hline
\end{tabular}

Tab. 3: Quality of Life Indicators in Connection with Respondents' Age Positive Aspects

\begin{tabular}{|l|c|c|c|}
\hline \multicolumn{1}{|c|}{ Wishes } & $\boldsymbol{\chi}^{2}$ & $\mathbf{P}$ & For grade \\
\hline Family House & 44.21 & $\mathrm{P}<0.01$ & $6^{\text {th }}$ grade \\
\hline Good Job & 12.51 & $\mathrm{P}<0.01$ & $6^{\text {th }}$ grade \\
\hline Car & 8.35 & $\mathrm{P}<0.01$ & $6^{\text {th }}$ grade \\
\hline Love & 6.79 & $\mathrm{P}<0.01$ & $9^{\text {th }}$ grade \\
\hline Health & 28.45 & $\mathrm{P}<0.01$ & $9^{\text {th }}$ grade \\
\hline Money & 38.23 & $\mathrm{P}<0.01$ & $9^{\text {th }}$ grade \\
\hline
\end{tabular}


Tab. 4: Quality of Life Indicators in Connection with Respondents' Age Negative Aspects

\begin{tabular}{|l|c|c|c|}
\hline \multicolumn{1}{|c|}{ Worries } & $\chi^{2}$ & $\mathbf{P}$ & For grade \\
\hline Illness & 17.9 & $\mathrm{P}<0.01$ & $9^{\text {th }}$ grade \\
\hline Accidents & 24.09 & $\mathrm{P}<0.01$ & $6^{\text {th }}$ grade \\
\hline War & 54.69 & $\mathrm{P}<0.01$ & $6^{\text {th }}$ grade \\
\hline Accident in Family & 18.91 & $\mathrm{P}<0.01$ & $9^{\text {th }}$ grade \\
\hline Lack of Success in Job & 20.18 & $\mathrm{P}<0.01$ & $9^{\text {th }}$ grade \\
\hline
\end{tabular}

The comparison of all life wishes and fears among pupils of $6^{\text {th }}$ and $9^{\text {th }}$ grades of the tested lower secondary school $\chi^{2}$ does not show any connection between the monitored and theoretical divisions. From the overview of the results of important indicators of quality of life stated above it can be concluded that older pupils who are at the age when they decide on their future life orientation and perceive the importance of interpersonal relationships that are represented here especially by love. They rate relationships above the material criteria of quality of life, i.e. like a family house, a car or money, which are rated higher by pupils from $6^{\text {th }}$ grade at the beginning of the adolescence.

The older adolescents have concrete life fears connected with illness, accident in family and lack of success. The last indicator is often in the context of job or education. The younger respondents express their fears more about extraordinary events such as accidents or wars. (Indicators overview is stated in Tables no. 5 and 6)

Tab. 5: Quality of Life Indicators in Connection with School Location - Positive Aspects

\begin{tabular}{|l|c|c|c|}
\hline \multicolumn{1}{|c|}{ Wishes } & $\chi^{2}$ & P & Place \\
\hline Good Job & 8.64 & $\mathrm{P}<0.01$ & Urban \\
\hline Car & 18.22 & $\mathrm{P}<0.01$ & Rural \\
\hline Love & 4.16 & $\mathrm{P}<0.05$ & Urban \\
\hline Career & 13.57 & $\mathrm{P}<0.05$ & Urban \\
\hline Good Luck, Happiness & 11.35 & $\mathrm{P}<0.01$ & Rural \\
\hline Money & 13.35 & $\mathrm{P}<0.01$ & Urban \\
\hline
\end{tabular}


Tab. 6: Quality of Life Indicators in Connection with School Location Negative Aspects

\begin{tabular}{|l|c|c|c|}
\hline \multicolumn{1}{|c|}{ Worries } & $\boldsymbol{\chi}^{2}$ & P & Place \\
\hline Spiders & 25.65 & $\mathrm{P}<0.01$ & Urban \\
\hline Homelessness & 9.20 & $\mathrm{P}<0.01$ & Rural \\
\hline Drugs & 7.15 & $\mathrm{P}<0.01$ & Rural \\
\hline Death & 5.11 & $\mathrm{P}<0.01$ & Urban \\
\hline Illness & 4.73 & $\mathrm{P}<0.05$ & Rural \\
\hline Disappointment & 7.19 & $\mathrm{P}<0.01$ & Rural \\
\hline Accident & 3.67 & $\mathrm{P}<0.05$ & Urban \\
\hline Accident & 8.43 & $\mathrm{P}<0.01$ & Urban \\
\hline
\end{tabular}

The presented data show that adolescents from the rural school highlight the importance of "car" and "happiness" as a criterion of quality of life. For the respondents from the urban school, "good job", "love", "career" and "money" are more important aspects. Apart from the relationship criterion of "love", it is obvious that the adolescents from the urban environment are more oriented to a good position at work where they can see their personal appreciation in contrast to the adolescents from rural school.

Differences between the urban and rural environments are evident in the area of fears - "fear of spiders" for the urban respondents in contrast to "homelessness", "drugs" and "disappointment" from other people that are fears of the rural adolescents. All the fears might be interpreted as something that the adolescents have low experience with. As a consequence this might increase their feeling of endangerment. The pupils from the rural school cannot imagine the loss of home. They usually feel secure in their own house. A similar fear concerns drugs. They know their effects from the media, where they may be usually over-dramatised. Disappointment from other people might also influence them more intensively because the number of contacts that may provide mainstay and understanding is in a smaller community scarcer than in a the urban environment. The stated criteria of the adolescents from the rural school might be connected to relatively stable material and social relations within the rural community where it is not as easy to obtain "different home" and "different friendships" as it is in municipal environment. 
The obtained results enable us to express our opinion on the given research question. The respondents aged from 11 to 16 years are able to work with the subjective questionnaire method of SEIQoL. The results of our investigation by their content provide documentary evidence for differences in quality of life indicators caused by the age and environment where the adolescents live and they can be compared also with the findings of other investigators who have worked with different research methods.

J. Mareš and A. Neusar (2007) used a projective questionnaire for pupils of basic schools aged from 8 to 15 years that dealt with their perceptions of quality of life. The questionnaire consisted of three tasks presented on A4 page, dealing with each task separately and with a graphically limited space for each answer. Children were asked to describe their idea of "bad", "average" and "excellent" life. They connected "bad life" with serious disease, not incomplete family, bad relationship among family members and not enough money. "Average life" was connected with certain defects in relationships, e.g. a divorce in family, arguments, temporary financial problems, while children do not live in beggary and do not complain about their life. "Excellent life" includes especially love of parents, an intact family, a good material background and a lot of friends.

Appreciation health as an important life value is usually neglected by children and adolescents. It is rather considered in relation to the possibility of disease (Škoda, Doulík, Hajerová-Müllerová, 2007). Our results also show that health as a separate criterion is considerably stated by older pupils only.

Quality of life of adolescents was investigated also by T. Svatoš and E. Švarcová in the period from 2006 to 2008. Respondents got 20 pictures on which various suggestions as indicators of life of good quality were stated. A task for every respondent was to select 12 of them which they consider important for definition of "quality of life". After that they selected 6 indicators from every set and determined their order according to their importance. The results in Czech pupils show a preference of the relational attributes to material ones: "having friends", "having age-mates", "having family", "living in nice family environment" and "having good rest".

Finding in all the respondents accent family relationships. Our research has a wider variance of indicators concerning the area of future careers. For this age group this effect is not shown in the quality of life researches made by different methods. Because the SEIQoL method does not establish certain 
criteria in advance, it does not limit a scope in which the respondents think and they are free to incorporate more categories that they envisage as defining of life of good quality. However, application of this method is limited by age. Our younger respondents who were aged between 11 and 12 years needed more explanations and confirmations of correctness of their answers. Adolescents aged between 14 and 16 years already have understood the task and they applied the method with greater understanding.

\section{Conclusion}

In our study we asked whether it is possible to apply the subjective questionnaire method of the SEIQoL for adolescents. The respondents of our sample were pupils of lower secondary schools aged from 11 to 16 years. We modified the method in the following way: the respondents first recorded their five wishes for the future and then five fears that they might meet in their lives. For every item according to the quality of life indicator they stated numerically (in \%) its importance or rate of displeasure. For the data processing we used a statistic test $\chi^{2}$ at d. f. 1 .

The composition of quality of life indicators corresponds to the respondents' age and it is influenced also by the urban or rural environment from which our respondents come from. The older students were more conscious of the importance of health and interpersonal relationships, the younger pupils preferred material values. The respondents from the urban school are more focused on ambitions concerning jobs in contrast to the rural school respondents. The older adolescents are more afraid of illness in the future, the younger ones are more afraid of extraordinary situations. But the rural and urban children have concrete worries of different indicators but what mostly worries them is what they do not have experience with (spiders, drugs, homelessness).

The research results confirm that the use of the SEIQoL method for adolescents is possible. Admittedly, at the beginning of adolescence respondents manage to complete the task but the researcher has to maintain a contact and verbal support while 11 and 12 years old children are completing the questionnaire. Adolescents between 14 and 15 year can think more independently and are better able to generalize their future wishes and life fears that define quality of their life. 


\section{References}

NEUSAR, Aleš, MAREŠ, Jiří. Quality of Life from Children's Point of View

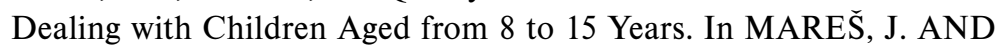
TEAM: Quality of Life of Children and Adolescents II. Brno: MSD 2007, pp. 139-158. ISBN 978-80-7392-008-1.

SVATOŠ, Tomáš, ŠVARCOVÁ, Eva. Quality of Life Indicators for Pupils of Basic Schools In MAREŠ, J. AND TEAM. Quality of Life of Children and Adolescents I. Brno: MSD, 2006, pp. 171-182, ISBN 80-86633-65-0.

ŠIMÍČKOVÁ-ČÍŽKOVÁ, Jitka. Monitoring of Teachers' and Teaching Profession Students' Quality of Life. In ŠIMÍČKOVÁ-ČÍŽKOVÁ, JITKA et al. Psychological Aspects at Teacher's Work, Ostrava: OU, 2010, pp. 96-01, ISBN 978-80-7368-913-1.

ŠIMÍČKOVÁ-ČÍŽKOVÁ, Jitka, VAŠINA, Bohumil, ŠIŠÁK, Petr. Health as an Aspect Quality of Life of University Students. In ŘEHULKA, Evžen. et al. School and Health 21: Contemporary School Practice and Health Education, Brno: MU, 2008, pp. 17-24, ISBN 978-80-7392-042-5.

Ǩ̌IVOHLAVÝ, Jaro. Psychology of Health. Prague: Portál, 2009, ISBN 978-80-7367-568-4.

ŠKODA, Jiří, DOULÍK, Pavel, HAJEROVÁ-MÜLLEROVÁ, Lenka. Kvalita života u skupin mládeže z odlišného sociokulturního prostředí. In Kvalita života u dètí a dospivajících II. Brno: MSD, 2007, pp. 191-208, ISBN 978-80-7392-008-1.

LUKÁŠOVÁ, Hana. Kvalita života dětí a didaktika. Praha: Portál 2010, ISBN 978-80-7367-784-8.

\section{Contact}

Doc. PhDr. Jitka Šimíčková-Čížková, CSc.

University of Ostrava

Department of Pedagogical and School Psychology

Fráni Šrámka 3

70900 Ostrava-Mariánské Hory

e-mail: jitka.cizkova@osu.cz 